\title{
DISPUTAS TRABALHISTAS EM COMARCAS DO INTERIOR: RECÔNCAVO DA BAHIA, 1940-1960.
}

\author{
Edinaldo Antonio Oliveira Souza*
}

\begin{abstract}
Resumo: As ações trabalhistas movimentadas nas Comarcas do Interior representam uma importante janela de acesso às experiências de algumas categorias de trabalhadores que raramente figuram nos estudos que se dedicam às grandes unidades de produção e às formas convencionais de organização e mobilização classistas (sindicatos, partidos, greves). Este texto discute as formas como os trabalhadores do Recôncavo Sul da Bahia acessaram informações e se relacionaram com as idéias e realizações do projeto trabalhista; notadamente com a legislação, a justiça do trabalho e o mito do "pai dos pobres". Avalia os significados que Ihes atribuíram e as condições em que acionaram. Sustenta a tese de que trabalhadores e Estado foram protagonistas de tal relação.
\end{abstract}

Palavras-chaves: trabalhadores - direitos - justiça.

Abstract: The work processes movement in the district of the Interior represent an important window of access to the experiences of some categories of workers that rarely are present in the study that dedicate to the big units of production and to the conventional forms of organization and classes mobilization (syndicates, parties, strikes). This paper discusses the ways that the workers of Recôncavo Sul in Bahia accessed information and related themselves with the ideas and accomplishments of the Labor project, especially with legislation, justice and the myth of "poor's fathers". It evaluates the meanings that attributed them and the conditions that activate it. It sustains the thesis that workers and State were protagonists of this relation.

Keywords: workers - rights - justice.

\section{A JUSTIÇA DO TRABALHO E AS COMARCAS DO INTERIOR.}

Em 1으 de maio de 1941, durante as comemorações do Dia do Trabalho, Getúlio Vargas anunciou aos trabalhadores o início do funcionamento da justiça do trabalho em todo o Brasil. A medida, a priori, se inseria no conjunto de esforços que o Estado vinha desenvolvendo desde a década de 1930, com a criação de leis e organismos, tendo como objetivo mediar as relações trabalhistas e empreender uma política de controle, manipulação e tutela sobre as classes trabalhadoras. ${ }^{1}$

\footnotetext{
* Mestre em História Social, professor da Universidade do Estado da Bahia, e-mail: edyaos@ig.com.br

${ }^{1}$ Ao longo das décadas de 1930 e 1940 diversas leis e decretos, além de duas constituições (a de 1934 e a de 1937) legislaram sobre a questão. As principais disposições aprovadas diziam respeito à regulamentação das práticas de trabalho, definição de direitos e obrigações e mediação dos conflitos entre patrões e empregados. Inseridas neste conjunto de esforços, foram criadas as Comissões Mistas de Conciliação (CMC), as Juntas de Conciliação e Julgamento (JCJ) e a Carteira de Trabalho, todas em 1932, ainda no período do Governo Provisório.
} 
A criação de uma justiça do trabalho já estava prevista nas Constituições de 1934 e de $1937^{2}$, mas o projeto de lei que a estruturava ocasionou uma longa discussão no Congresso Nacional, cujas principais controvérsias diziam respeito à representação classista (inclusive quanto ao custo financeiro), ao poder normativo e, antes de tudo, à resistência dos representantes patronais. Depois de longos debates, a regulamentação finalmente ocorreria com a publicação do decreto-lei 1.237, de 1939. A instalação, porém, somente ocorreria dois anos mais tarde, sendo solenemente anunciada por Getúlio Vargas, durante o ato público de comemoração do dia do trabalho, em 10 de maio de 1941.

A justiça do trabalho representaria, segundo seus idealizadores, um "processo específico, rápido, eficiente e pouco oneroso" de aplicar e fazer cumprir a legislação trabalhista que, até então, vinha perdendo a sua eficiência. ${ }^{3}$ Além de dispensar a necessidade de contratação de um advogado, o acesso à instituição não estava condicionado ao pré-requisito da sindicalização. Embora, da perspectiva do funcionamento prático, a situação se revelasse bem mais complexa, esses enunciados possuem alguma relevância, haja vista que poucas categorias de trabalhadores do Recôncavo possuíam sindicato na época, e que, mesmo entre as que possuíam, o número de sindicalizados era reduzido.

De acordo com o decreto-lei que a regulamentou, a justiça do trabalho seria exercida por três instâncias: as Juntas de Conciliação e Julgamento (JCJ) e Juízes de Direito; os Conselhos Regionais do Trabalho (CRT) e o Conselho Nacional do Trabalho (CNT) "na plenitude de sua composição, ou por intermédio de sua Câmara de Justiça do Trabalho (CJT)". Em seu artigo quinto, o referido decreto previa que, nas localidades onde o Governo não provesse sobre a criação de Juntas, competia aos juízes de Direito das Comarcas a administração da instituição. ${ }^{4}$ Apesar da pouca atenção que tem recebido na maioria das análises, este aspecto se reveste de grande importância na medida em que ampliava consideravelmente o raio de alcance daquele organismo judicial, promovendo, ainda que precariamente, a sua interiorização territorial.

Para termos uma idéia do papel desempenhado pelos juízes de Direito das Comarcas na aproximação entre a justiça do trabalho e os trabalhadores de cidades do interior - e até mesmo dos rurais -, basta lembrar que em 1947 existiam apenas 54 JCJ

\footnotetext{
2 Ver: Constituição de 1934, Título IV e Constituição de 1937, art. 139.

${ }^{3}$ Cf. Entrevista do Ministro do Trabalho Valdemar Falcão. Diário da Bahia, 1/5/1941, p. 2.

${ }^{4}$ Tal disposição foi mantida na CLT (1943) e na Constituição de 1946.
} 
funcionando em todo o Brasil. Apenas três delas estavam localizadas na Bahia, todas em Salvador. Posteriormente, através da Lei № 3.492 de $1958^{5}$, foram criadas cinco novas Juntas no Estado, sendo duas em Salvador e as outras três no interior, nas cidades de Itabuna, Valença e Cachoeira - esta última no Recôncavo. Todavia, a jurisdição de cada Junta estava limitada a alguns poucos municípios - a primeira atuava sobre as Comarcas de Itabuna e Ilhéus; a segunda sobre as Comarcas de Valença, Taperoá e Nilo Peçanha e a terceira sobre as Comarcas de Cachoeira, São Felix, São Gonçalo dos Campos e Maragogipe. Permaneceu, portanto, sobre amplo território, a jurisprudência dos juízes de Direito.

O Decreto-lei 1.237 de 1939 definiu ainda que as principais competências das Juntas seriam: promover a conciliação e julgamento dos dissídios individuais e das reclamações que envolvam o reconhecimento da estabilidade de empregados e executar as decisões proferidas nos processos de sua competência originária. Cabia-Ihes também, dentre outras atribuições, a conciliação e o julgamento dos dissídios em contratos de empreitada em que o empreiteiro seja operário ou artífice. Os dissídios individuais, quando concernentes a salários, férias e indenizações por despedida injusta, de valor igual ou inferior á alçada fixada no art. $95^{6}$, seriam julgados em única instância, não sendo admitido, da respectiva sentença, outro recurso, senão na própria Junta. As mesmas atribuições estavam asseguradas aos juízes de Direito, salvo que, a alçada dos juízos do interior dos Estados correspondia à metade da alçada das JCJ da respectiva capital. ${ }^{7}$

Em casos de dissídio individual, o trabalhador poderia apresentar sua reclamação escrita ou verbal ao secretário da Junta ou ao escrivão da Comarca. Quando apresentada verbalmente, ela seria "reduzida a termo" e assinada pelo próprio secretário; se escrita, deveria ser assinada pelo reclamante ou pelo representante do sindicato. Nesse momento já seriam "arroladas" as testemunhas, em número máximo de três por cada parte. Tratando-se de várias reclamações apresentadas por empregados de uma mesma empresa ou estabelecimento e havendo identidade de matéria, poderiam ser acumuladas num só

\footnotetext{
${ }^{5}$ A referida lei elevou à Primeira Categoria os Tribunais do Trabalho das 3ạ , 5a e 6a Regiões, aumentando o número de seus juízes para sete, e criou 20 (vinte) novas JCJ. Seis delas na 5ạ Região, sendo duas em Salvador e três no interior, respectivamente nas cidades de Itabuna, Cachoeira e Valença e a outra na cidade de Estância, interior de Sergipe.

${ }^{6}$ O referido artigo fixou para Salvador a alçada de $600 \$ 000$ (seiscentos mil réis). A alçada dos Juízos do Interior dos Estados seria igual à metade da alçada da Junta da respectiva capital.

7 Cf. arts. 24, 25, 26, 27, 74 e 95 do Decreto-Lei 1.237 de 1939.
} 
processo. A reclamação poderia ser encaminhada também por intermédio da Procuradoria do Trabalho. ${ }^{8}$

A princípio a justiça do trabalho esteve vinculada ao Ministério do Trabalho, portanto ao Poder Executivo, somente passando a integrar o Judiciário na Constituição de 1946. ${ }^{9}$ A Consolidação das Leis do Trabalho (CLT), promulgada no primeiro de maio de 1943, apenas ratificou o que já estava previsto na legislação anteriormente aprovada. A Carta de 1946, por seu turno, acatando o que já estava inscrito no Decreto-lei 9.797 de 9 de setembro daquele mesmo ano, transformou os CRT e o CNT, respectivamente, em Tribunais Regionais do Trabalho (TRT) e Tribunal Superior do Trabalho (TST) e integrou a Justiça do Trabalho ao Poder Judiciário. As JCJ foram mantidas, ficando assegurada também a paridade de representação de empregados e empregadores, bem como, a competência dos juízes de Direito para substituí-las, "nas Comarcas onde elas não forem instituídas". ${ }^{10}$ Até a promulgação da Constituição de 1988, poucas alterações foram processadas no que concerne a tais preceitos.

Embora não fosse suficiente para garantir uma pretensa neutralidade à justiça do trabalho, a participação de representantes classistas na composição das JCJ, além de funcionar como um elemento de legitimação da instituição contribuía para o expediente da conciliação, principal tarefa para a qual foi instituída. A combinação desses dois fatores presença da representação operária e necessidade de legitimidade e prestígio da instituição - pode ter contribuído, ainda, para a realização de sentenças favoráveis aos trabalhadores. Contudo, segundo Fernando Teixeira da Silva, "há registros de que os vogais teriam tido pouco peso no processo decisório, referendavam as decisões dos juízes de carreira e votavam até mesmo contra os interesses da sua classe, solapando, assim, o caráter paritário da justiça trabalhista". ${ }^{11}$

Nas Comarcas, porém, as decisões competiam exclusivamente aos juízes de Direito. Em tais circunstâncias, as diversas estratégias empenhadas pelos reclamantes - a mobilização de provas testemunhais e documentais, a busca de aliados entre advogados,

\footnotetext{
${ }^{8}$ Cf. art. 140, parágrafos 1ำ e 3o do Decreto-Lei 1.237 de 1939.

9 A inclusão da Justiça do Trabalho no âmbito do Poder Judiciário foi uma das bandeiras defendidas pela bancada comunista que participou da discussão e aprovação do projeto, na Assembléia Constituinte, em 1946 (O Momento, 28/04/1946, p.1).

${ }_{10}$ Constituição de 1946, Capítulo IV, Art. 122, parágrafo 3‥

11 SILVA, Fernando Teixeira. "Justiça do Trabalho e Magistratura del Lavoro: apontamentos comparativos". Manuscrito, s.d., p. 4.
} 
sindicato (quando dispunham), políticos e outras autoridades e a argumentação utilizada poderiam fazer a diferença. As práticas de sociabilidade realizadas dentro e fora do local de trabalho e as informações que eram capazes de processar teriam um papel fundamental.

\section{ECOS DO TRABALHISMO NO RECÔNCAVO BAIANO.}

É bastante provável que naquela quinta-feira, 1 을 de maio de 1941 , muitos dos trabalhadores do Recôncavo estivessem ocupados demais com suas atividades cotidianas para acompanharem o anúncio do Presidente. Contudo, numa época em que a propaganda era amplamente utilizada como estratégia do jogo político para alcançar as "massas", não tardaria para que ficassem sabendo da existência da justiça do trabalho e logo a convertessem em possível instrumento a ser empregado nas suas lutas por direitos. Destarte, faz-se necessário identificarmos os canais através dos quais eles acessavam tais informações, bem como as formas, o ritmo e a intensidade com que elas eram recepcionadas.

Primeiramente, não podemos desconsiderar a possibilidade de alguns trabalhadores terem acessado a justiça antes de 1930, ainda que eventualmente, para resolver questões atinentes às relações de trabalho, conquanto enfrentassem o "forte bloqueio do patronato" ${ }^{12}$ Para tanto, poderiam lançar mão da legislação existente, como o Código Civil de $1916^{13}$ e a lei de acidentes de trabalho de $1919^{14}$ - freqüentemente citados em processos do início da década de 1940 - e acionarem a justiça com alguma modalidade de processo cível ou crime. Ao longo da década de 1930, à medida que novas leis eram aprovadas, pode ter havido algum incremento nesse tipo de iniciativa. Contudo, foi somente a partir da década de 40, com o início do funcionamento da justiça do trabalho, que tal iniciativa passou a ocorrer de forma mais regular nas Comarcas do Recôncavo.

No início da década de 1940 alguns trabalhadores do Recôncavo Sul já demonstravam algum conhecimento das leis trabalhistas e da justiça do trabalho. Tão logo esta última entrou em vigor, não tardou para que as primeiras reclamações fossem

\footnotetext{
12 GOMES, Ângela de Castro. A Invenção do Trabalhismo. 3. ed. Rio de Janeiro: Editora FGV, 2005, p. 145.

13 O Código Civil Brasileiro de 1916, em seus arts. 1216 a 1236, já legislava sobre a contratação e dispensa de serviços.

${ }^{14}$ Refiro-me ao Decreto 3.724 de 15/1/1919, que obrigava as empresas a instituir o seguro de acidentes de trabalho para os seus empregados.
} 
formuladas em Comarcas da região. Em 12 de setembro de 1941 o operário Pedro Alfredo do Nascimento, residente na cidade de Cachoeira e identificado profissionalmente como "prenseiro", apresentou uma reclamação trabalhista, na Comarca local, contra a Firma Arnaldo de Sá, armazém de fumo onde trabalhava desde 13 de abril de 1939. Em sua queixa, ele alegou ter sido "dispensado do trabalho" no dia 23 de agosto daquele ano, sem receber aviso prévio conforme previa art. 1221 do Código Civil ${ }^{15}$, nem a sua indenização de acordo com o art. 2o, da Lei 62 de 5/6/1935 ${ }^{16}$. Na ocasião, apresentou-se acompanhado de um fiscal do trabalho. ${ }^{17}$

Cerca de dois meses depois, outro operário, chamado Arnaldo do Carmo, também apresentaria, na mesma Comarca, uma reclamação contra a firma Lucas Evangelista Cidreira, onde fora admitido em maio de 1935. Conforme afirmou, em junho de 1941, fora "demitido sem justa causa, sem nunca ter gozado férias". Destarte, requereu que, "mui respeitosamente", o juiz da Comarca mandasse processar sua reclamação, citando como anteparo legal, além dos arts. 1ㅇ e 2ㅇ da Lei 62, os arts. 8ㅇ e 27음 do Decreto 23.768 de $18 / 01 / 934^{18}$ e o "regulamento a que se refere o Decreto 6.596 de 12/12/1940". ${ }^{19}$ Por fim esclareceu que não era sindicalizado, "por não existir o sindicato da classe neste município". ${ }^{20}$

Simultaneamente, na Comarca de Nazaré, outras reclamações eram formuladas. Em 19 de julho de 1941, o operário Juvenal Martins dos Santos, acompanhado por um fiscal da Delegacia Regional do Trabalho (DRT), ingressou com um processo de dissídio individual

${ }^{15}$ O Código Civil de 1916, em seu art. 1.221 já previa que não havendo prazo estipulado, nem se podendo inferir da natureza do contrato, ou do costume do lugar, qualquer das partes, a seu arbítrio, poderia rescindir o contrato, mas "mediante prévio aviso". Este, de acordo com o parágrafo único, dar-se-ia: com antecedência de 8 (oito) dias, se o salário estivesse fixado por tempo de 1 (um) mês, ou mais; com antecipação de 4 (quatro) dias, se o salário tivesse sido ajustado por semana, ou quinzena; de véspera, quando contratado por menos de 7 (sete) dias.

16 Conhecida como a "Lei da Despedida", assegurava aos trabalhadores da indústria e do comércio o direito ao emprego; estabilidade, após dez anos de trabalho prestados na mesma empresa e instituiu a indenização por despedida injusta àqueles que não haviam cumprido os dez anos. Cf. DECKER, Elton Luiz. "A importância da Lei 62/35". Memorial da Justiça do Trabalho do Rio Grande do Sul. Disponível em: http://iframe.trt4.jus.br/portaltrt/htm/memorial/index.htm.

17 Autos da Reclamação Trabalhista de Pedro Alfredo Nascimento, contra a firma Arnaldo Pimentel de Sá; Comarca de Cachoeira, 12/9/1941. Arquivo Público Municipal de Cachoeira (APMC), Reclamações Trabalhistas, 1941-1949.

18 Regulou a concessão do direito de férias aos empregados na indústria, limitando-o apenas aos sindicalizados.

${ }_{19}$ O referido Decreto legislava sobre a regulamentação do funcionamento da Justiça do Trabalho.

${ }^{20}$ Autos da Reclamação Trabalhista de Arnaldo do Carmo, contra a firma Lucas Evangelista Cidreira; Comarca de Cachoeira, 4/11/1941. APMC, Reclamações Trabalhistas, 1941-1949. 
contra o curtume Drault e Cia Ltda, onde trabalhara desde 1938, alegando demissão injustificada e sem indenização. Segundo o fiscal do trabalho que o acompanhava, o patrão teria afirmado que o havia dispensado "em virtude da lei que fixou o salário mínimo". ${ }^{21} \mathrm{Em}$ 22 de novembro daquele mesmo ano, Humberto Costa e Silva formulou uma ação de indenização contra a Estrada de Ferro de Nazaré, onde trabalhava desde setembro de 1936 como "administrador de Trecho". ${ }^{22}$ Nela, alegou demissão sem justa causa, inobservância da Lei 62 e requereu que sua reclamação fosse julgada com as formalidades previstas nos arts. 6 a 19 do Decreto Federal 22.132 de 25/11/1932. ${ }^{23}$ Ainda em 1941, no dia 16 de dezembro, foi José da Costa Nascimento que registrou uma ação de dissídio contra o armazém de fumo Luiz Barreto Filho e Cia, onde trabalhara desde 27 de abril de 1940, também alegando demissão injustificada. Por não saber ler nem escrever (o reclamante) a queixa foi formulada por um tal Alfredo Leão da Costa, a seu pedido. ${ }^{24}$

Trata-se de pequenos processos que tiveram curta duração, haja vista que os dois primeiros resultaram em conciliação em primeira instância, logo nas primeiras audiências. Apenas o processo de Juvenal Martins dos Santos foi remetido para a 3a JCJ, em Salvador, onde foi julgado improcedente. Contudo, são dignos de nota, por indicarem que alguns trabalhadores do Recôncavo não tardaram em tomar conhecimento do funcionamento da justiça do trabalho e que logo tiveram a iniciativa de experimentá-la. Antecipando-se à criação da primeira Junta do Trabalho na região, souberam encaminhar suas reclamações através dos juizes de Direito das Comarcas e foram capazes de acessar informações precisas sobre a legislação trabalhista existente, a exemplo do Código Civil de 1916 e da Lei 62 de 1935, respectivamente, nos casos envolvendo descumprimento do aviso prévio e demissão injustificada. Um estudo realizado pelo Memorial da Justiça do Trabalho do Rio Grande do Sul demonstra que a lei 62 também vigorou de forma destacada naquele tribunal. ${ }^{25}$

Sabe-se que desde 1938 o Estado vinha articulando uma poderosa máquina de propaganda política capitaneada pelo Departamento de Imprensa e Propaganda (DIP),

\footnotetext{
${ }^{21}$ Autos do Processo de Dissídio Individual de Juvenal Martins dos Santos, contra Drault e Cia Ltda; Comarca de Nazaré, 19/7/1941. Acervo do Fórum de Nazaré (AFN), documento sem catalogação.

${ }^{22}$ Autos da Ação de Indenização de Humberto Costa e Silva, contra a Estrada de Ferro de Nazaré; Comarca de Nazaré, 22/11/1941. AFN, documento sem catalogação.

${ }^{23}$ Especifica as atribuições das Juntas de Conciliação e Julgamento.

${ }^{24}$ Autos da Ação de Dissídio de José Costa Nascimento, contra Luiz Barreto Filho e Cia; Comarca de Nazaré, 16 de dezembro de 1941. AFN, documento sem catalogação.

${ }^{25}$ Cf. DECKER, op. cit.
} 
buscando estabelecer uma comunicação direta com os trabalhadores. Para isso, fazia uso dos mais diversos meios disponíveis. ${ }^{26} \mathrm{~A}$ imprensa e o rádio foram "os veículos privilegiados para transmissão das mensagens de propaganda", conquanto o cinema também recebeu atenção especial. ${ }^{27}$ Todavia, embora os referidos instrumentos de comunicação, em geral, já estivessem presentes em muitas cidades do Recôncavo, alguns obstáculos poderiam limitar seu raio de alcance entre os trabalhadores. O rádio ainda era considerado um objeto de luxo em localidades do interior; problemas de ordem técnica e de distribuição de renda limitavam seu acesso a muitos dos operários estudados. O cinema, por motivos culturais e econômicos, provavelmente, também ainda não havia se popularizado na região. A imprensa e a escola, por sua vez, encontravam a forte barreira do analfabetismo. ${ }^{28}$ Além disso, como sugere Maria Helena Rolim Capelato,

a propaganda política desencadeia uma luta de forças simbólicas, que visa ao reforço da dominação, ao consentimento em relação ao poder e à interiorização das normas impostas através das mensagens propagandísticas. No entanto, como esclarecem De Certau e Chartier, a incorporação da dominação pelo receptor não exclui a possibilidades de desvios. A eficácia das mensagens depende dos códigos de afetividade, costumes e elementos histórico-culturais dos receptores. Por isso, o efeito não é unívoco, e mensagens similares podem ser interpretadas de maneiras diferentes, produzindo ações diferentes. ${ }^{29}$

Assim sendo, é preciso reconhecer a existência de alguns canais de informações não monitorados pelo DIP, bem como a possibilidade de apropriação e re-significação das mensagens por parte dos trabalhadores. Estas poderiam ser acessadas de forma indireta, pois existia uma importante rede de comunicações que extrapolava os limites dos veículos oficiais. Era o sistema do "ouvi dizer", "fulano me contou". Uma cadeia que podia iniciar-se com alguém, não necessariamente um trabalhador, que acessara a informação através do rádio, do jornal ou de uma faixa erguida durante uma festividade do Dia do Trabalho ou do aniversário de Getúlio Vargas e daí propagá-la em várias direções.

\footnotetext{
${ }^{26}$ Com este fim foram produzidos livros, revistas, folhetos, fotos, cartazes, programas de rádio, cinejornais, documentários cinematográficos, etc.

27 CAPELATO, Maria Helena Rolim. "Estado Novo: Novas Histórias". In: FREITAS, Marcos Cezar (Org.). Historiografia brasileira em perspectiva. 5. ed., São Paulo: Contexto, 2003, pp. 203-209.

${ }^{28}$ Situações informadas pela imprensa da época, pelas entrevistas que realizamos com os trabalhadores e pelos censos de 1940 e 1950.

${ }^{29}$ CAPELATO, op. cit., pp. 202-203.
} 
Outrossim, não podemos subestimar a atuação de militantes de vários matizes junto a algumas categorias de trabalhadores do Recôncavo. Notadamente, a partir de 1945, com a criação do Partido Trabalhista Brasileiro (PTB) e o retorno do Partido Comunista (PCB) à legalidade, trabalhistas e comunistas iniciaram uma intensa disputa pela conquista de representatividade no meio operário, ambos marcando presença na região. Em comício realizado na cidade de Cachoeira, no dia 30 de dezembro de 1945, o dirigente comunista municipal, José Maria Rodrigues, exortou os trabalhadores a se organizarem em Movimentos Unificados dos Trabalhadores (MUT), a unirem-se em Comitês Democráticos Populares (CDP) e a sindicalizarem-se, conforme os trechos a seguir:

O Partido Comunista do Brasil, vanguarda organizada e consciente da classe operária e do povo, vem trazer-vos sua palavra de esclarecimento pela voz de seus legítimos representantes, apontando-vos os meios de lutardes, eficientemente por vossas reivindicações. É necessário que o povo se organize. [...] Organizai-vos, pois em Movimentos Unificados dos Trabalhadores, reuni-vos em Comitês Populares Democráticos para levantardes as reivindicações mais sentidas deste Município. Trabalhadores! Sindicalizai-vos. Vosso candidato é vosso órgão de classe, é a vossa arma, meio mais eficaz de defenderdes vossos interesses. O P. C. luta pela União Nacional $[\ldots]^{30}$

Por seu turno, o Correio Trabalhista, periódico ligado ao PTB, em 19 de fevereiro de 1946, fazia o seguinte apelo aos trabalhadores do interior:

Trabalhador do Interior,

Se queres que teu direito seja defendido... Se almejas uma vida melhor...

Se desejas saúde e instrução gratuita primária, profissional e secundária para os teus filhos... Procure a sede do "Partido Trabalhista" nesse município e faça tua inscrição. ${ }^{31}$

Enquanto os comunistas investiam na criação de CDP, MUT e de Comitês Municipais do PCB; organizavam comícios e disputavam eleições em alguns municípios do Recôncavo, os trabalhistas, por sua vez, utilizavam-se da imagem de Getúlio Vargas e das suas realizações políticas, marcando presença nas festividades, nas inaugurações de obras e em comícios, ao mesmo tempo em que organizavam diretórios municipais do PTB, promoviam

\footnotetext{
30 O Momento, 7/1/1946, p. 6.

${ }^{31}$ Correio Trabalhista, 19/2/1946, p. 6.
} 
campanhas de filiação e disputavam as eleições, elegendo vereadores, deputados e prefeitos em municípios da região. ${ }^{32}$

As informações que dispomos dão conta de que os dois grupos políticos tiveram uma atuação importante nos municípios de Santo Amaro, Cachoeira e São Félix, onde havia maiores concentrações operárias, representadas, notadamente, pelos setores açucareiro e fumageiro. Os comunistas marcaram presença ainda em municípios como Maragogipe, Muritiba, Nazaré, Amargosa, Santo Antonio de Jesus, Santa Inês e outros. O PTB, por seu turno, tornava-se uma importante força política, elegendo prefeitos, vereadores e até deputados em vários municípios do Recôncavo. Joací Cunha observou que "o período de vida legal do PCB possibilitou a Santo Amaro ouvir, publicamente, pronunciamentos de líderes políticos tidos como subversivos até poucos meses antes" da sua legalização. ${ }^{33}$ Comícios e atos públicos foram realizados também em Cachoeira, São Félix e noutras cidades do Recôncavo. Todavia, com exceção desses três últimos municípios - notadamente entre os operários do açúcar e do fumo - não dispomos de informações mais precisas sobre o nível de envolvimento das militâncias com o conjunto dos trabalhadores da região.

Certo é que, na disputa por representatividade, tanto comunistas quanto trabalhistas buscaram inserir-se em algumas categorias de trabalhadores do Recôncavo e exerceram alguma influência nas suas representações classistas. ${ }^{34}$ Em tais empreitadas, a legislação trabalhista e as instituições criadas para a sua garantia sempre foram temas recorrentes, seja como objeto de contemplação e de exaltação das suas virtudes - no caso dos trabalhistas, ou de crítica aos limites e imperfeições - pelo lado dos comunistas. Ambos acabaram contribuindo para a divulgação das realizações da política trabalhista, pari passu à ampliação do clima de tensão entre patrões e empregados. Contudo, não sabemos

\footnotetext{
32 Sobre a atuação de comunistas e trabalhistas no Recôncavo, ver, respectivamente, $O$ Momento e periódicos ligados ao PTB, como Correio Trabalhista e o Correio de São Felix. Ver também CUNHA, J. S. Amargo açúcar: aspectos da história do trabalho e do capital no Recôncavo açucareiro da Bahia (1945-1964). Dissertação de Mestrado em História Social, Universidade do Estado da Bahia, Salvador, Ba, 1995.

33 CUNHA, op. cit., p.112.

${ }^{34}$ CUNHA, (op. cit.), destacou a atuação comunista entre os trabalhadores do açúcar e junto a outras categorias, em Santo Amaro, entre as décadas de 40 a 60, e suas relações com os trabalhistas. De acordo com O Momento, os comunistas marcaram presença não somente nos municípios de maior concentração operária: Santo Amaro, Cachoeira e São Félix, mas também em vários outros, como Maragogipe, Muritiba, Nazaré, Amargosa, Santo Antonio de Jesus, Santa Inês, com a criação de CDPs, de Comitês Municipais do PCB e do MUT.
} 
exatamente qual foi o alcance e o grau de influência do discurso militante sobre o conjunto dos trabalhadores que acessaram a justiça no período estudado.

Muitos dos que acionaram a justiça contaram ainda com a assessoria jurídica de advogados, fiscais do trabalho, representantes do Ministério Público e dirigentes sindicais quando dispunham. Outros tiveram apenas o auxílio do escrivão da Comarca, ao formularem suas reclamações. As práticas de sociabilidade realizadas dentro e fora do local de trabalho, as informações que eram capazes de processar, a mobilização de provas testemunhais e documentais, a busca de aliados entre bacharéis, sindicatos, políticos e outras autoridades e a escolha de um advogado, poderiam ter um papel fundamental no andamento do processo. Tudo isto demonstra as múltiplas iniciativas a que se lançaram na luta por direitos.

Apesar das agruras inerentes à própria lida cotidiana, os trabalhadores foram (e são) capazes de enxergar muito além do próprio nariz. Problemas tecnológicos, distância dos grandes centros e analfabetismo, não impediram que, mesmo nas pequenas cidades e localidades do interior, eles acessassem informações sobre os discursos e as realizações do projeto trabalhista. Captadas através de diferentes canais, elas poderiam ser processadas, decodificadas e re-inventadas a partir da experiência vivida. Subjacente a tal processo havia um passado rico em tradições e costumes que, provavelmente, informavam noções de direito e de justiça - além de possíveis estratégias a serem empreendidas para acessá-los que poderiam ser utilizados, a depender das circunstâncias, tanto para a legitimação quanto para o questionamento das experiências presentes.

Algumas noções de direitos e de justiça já poderiam se encontrar historicamente imbricadas na própria cultura dos trabalhadores da região. Estudos sobre o século XIX têm avaliado que mesmo no contexto da escravidão havia "códigos costumeiros" de direito, que muitas vezes definiam os limites do que era "justo" ou "injusto" nas relações entre senhores e escravos. Com o tempo, algumas dessas noções teriam sido adaptadas às práticas de trabalho livre e incorporadas ao conjunto de normas que comporiam os contratos informais de trabalho, largamente utilizados no tempo e espaço a que se refere esta pesquisa.

Estudando as experiências de trabalhadores rurais do Recôncavo Sul, na segunda metade do século XX, Charles Santana observou que "nas representações dos lavradores e nas atitudes dos fazendeiros, quanto à CLT, surpreende-se a força das leis consuetudinárias e 
da oralidade" orientando "os acordos de trabalho no mundo rural". ${ }^{35}$ Parafraseando E. P. Thompson, podemos inferir que os trabalhadores, provavelmente, há tempos conviviam "em suas ocupações diárias" com "estruturas legais visíveis ou invisíveis" e com "códigos costumeiros" de direitos que definiam as condições a serem acordadas nos seus contratos de trabalho. Mesmo porque a própria lei, "muitas vezes, era uma definição da efetiva prática" $^{36}$ empreendida cotidianamente por trabalhadores e patrões.

Estudos recentes, que tratam das experiências de trabalhadores rurais do Recôncavo Sul, no período em questão, têm avaliado que na esteira de uma tradição paternalista, permeada por redes de proteção e dependência - que tinha como uma das suas marcas mais visíveis as relações de compadrio - construíram-se noções de compromisso e reciprocidade. Estas, não impediam, entretanto, a existência de um intrincado jogo de interesses, de disputas e negociações que caracterizava o cotidiano das relações entre patronos e dependentes. Em tais condições, os termos dos contratos informais de trabalho, por vezes, eram cuidadosamente negociados pelos empregados. Agindo de forma cautelosa, com uma certa dose de astúcia e sagacidade, eles eram capazes de extrair dos patrões algumas importantes vantagens. Estas, com o tempo constituíam noções tácitas de direito, que ajudavam a definir padrões do que seria considerado justo ou injusto nas relações de trabalho. ${ }^{37}$

A convivência dos trabalhadores entre experiências do mundo rural e do urbano, a inexistência de limites demarcados entre elas, permitiu que algumas dessas noções fossem re-significadas no universo das relações assalariadas. ${ }^{38}$ Proteção, favor e compromisso integrariam, portanto, o vocabulário de diferentes categorias operárias ao se relacionarem tanto com patrões como com autoridades públicas e com sindicatos. Geralmente

\footnotetext{
35 SANTANA, Charles d'Almeida. Fartura e ventura camponesas: trabalho, cotidiano e migrações: Bahia 19501980. São Paulo: Annablume, 1998, p. 116.

${ }^{36}$ THOMPSON, E. P. Senhores e caçadores: a origem da lei negra. Rio de Janeiro: Paz e Terra, 1987, pp. 351352.

${ }^{37}$ A este respeito, ver: SANTANA, op. cit.; SOUZA, Edinelia Ma Oliveira. Memórias e tradições: viveres de trabalhadores rurais do município de Dom Macedo Costa - Bahia (1930-1960). Dissertação de Mestrado em História, Pontifícia Universidade Católica de São Paulo (PUC), São Paulo, 1999.

${ }^{38}$ A respeito da convivência de experiências rurais e urbanas entre os trabalhadores do Recôncavo Sul e sobre os possíveis intercâmbios culturais entre ambas, ver: SILVA ASSIS, Cristina da Anunciação. Os trabalhadores dos armazéns de fumo, Santo Antonio de Jesus: 1970-1980. Monografia de Especialização; Universidade do Estado da Bahia (UNEB), Santo Antonio de Jesus - Ba, 2004. Ver também SILVA, E. R. da. Fazer charutos: uma atividade feminina. Dissertação de Mestrado em História, Universidade Federal da Bahia, Salvador, Ba, 2001.
} 
impregnadas por noções de honra, respeito e dignidade, tais expressões poderiam carregar expectativas peculiares de direitos e de justiça. ${ }^{39}$

Mesmo se considerarmos a lei, o direito e a justiça, sob o ponto de vista formal, não podemos esquecer que desde, pelo menos, a segunda metade do século XIX, havia uma tendência de popularização na região estudada, favorecida pelo avanço da campanha abolicionista. A divulgação dos projetos de leis que estavam sendo discutidos e aprovados no Parlamento e a formulação de ações de emancipação baseadas em tal legislação faziam parte das estratégias utilizadas pelos abolicionistas no Recôncavo e logo se configurariam também em iniciativas partidas dos próprios escravos.

Já no cenário republicano, a questão dos diretos sociais e de garantias legais à sua realização, foi uma bandeira levantada por várias categorias operárias que participaram dos movimentos grevistas, especialmente nas décadas de 10 e 20 e resultaram na aprovação de alguns projetos afins. Segundo Aldrin Castellucci, operários de várias cidades do Recôncavo, como Nazaré, São Félix, Muritiba e Cachoeira aderiram à greve geral de 1919, onde lutaram "por salários mais altos e menor jornada de trabalho". ${ }^{40} \mathrm{O}$ recurso à intervenção de advogados e de juízes também fazia parte do repertório de estratégias da luta por direitos empreendida pelos trabalhadores, desde o início da República.

Não pretendo sustentar, com isso, "nenhum postulado quanto à imparcialidade abstrata e extra-histórica" a respeito da lei e da justiça. Afinal num contexto de flagrantes desigualdades de cor e classe "a igualdade da lei em alguma parte sempre será uma impostura". ${ }^{41}$ Tampouco negar que a legislação trabalhista e a justiça do trabalho, assim como outros sistemas jurídicos, tivessem sido instituídos com o propósito velado de "mediar as relações de classe existentes" e que isto favorecia os dominantes. ${ }^{42}$ Mas, talvez seja oportuno ponderar que os trabalhadores ao recepcionarem os discursos e propostas do projeto trabalhista, provavelmente não estivessem simplesmente endossando uma retórica vazia, ou uma simples panacéia ideológica imposta a partir de cima, sem nenhuma

\footnotetext{
39 Para uma discussão sobre cultura política popular e noções de direito e justiça entre trabalhadores, no pós 1930, ver: REIS, José Roberto F. "Cartas a Vargas: entre o favor, o direito e a luta política pela sobrevivência". In: Locus: Juiz de Fora, vol. 7, no 2, 2001. Ver também: FERREIRA, Jorge Luiz. Trabalhadores do Brasil: o imaginário do povo. Rio de Janeiro: Editora da FGV, 1997.

${ }^{40}$ CASTELLUCCI, Aldrin A. Industriais e operários baianos numa conjuntura de crise. Salvador: Fieb, 2004, p. 230.

${ }^{41}$ THOMPSON, E. P., Senhores e caçadores, op. cit., p. 357.

42 Ibidem, p. 356.
} 
possibilidade de compreensão ou de interferência crítica. Ao referir-se a leis, direitos e justiça, tal discurso poderia encontrar ressonância em experiências passadas ou de vida e, portanto, na própria cultura dos trabalhadores.

Portanto, os papéis da legislação trabalhista e da justiça do trabalho não podem ser compreendidos tomando-se como perspectiva apenas as intenções estatais. Entre aquilo que pretendia o Estado e a forma como foram recebidas pelos trabalhadores aconteceram desvios, apropriações, re-significações dos seus propósitos. Como se sabe, os trabalhadores não eram papéis em branco esperando para ser grafados. Nem garfados.

\section{UM PERFIL DOS RECLAMANTES}

A partir dos dados levantados num conjunto de 128 processos analisados, observou-se que mais de $65 \%$ dos reclamantes sabiam ler e escrever; aproximadamente $30 \%$ não sabiam e em relação aos cerca de $5 \%$ restantes não há referências expressas de que não soubessem, porém não constavam assinaturas. Vejamos, na tabela abaixo, uma demonstração do grau de instrução dos reclamantes, conforme o inventário de dados obtidos nos processos consultados das três Comarcas e da JCJ estudadas.

TABELA 1 - RECLAMANTES X INSTRUÇÃO ESCOLAR.

\begin{tabular}{|l|l|l|l|l|l|c|}
\hline Comarcas e JCJ & $\begin{array}{l}\text { Período } \\
\text { Coberto }\end{array}$ & $\begin{array}{l}\text { No de } \\
\text { Processos }\end{array}$ & $\begin{array}{l}\text { Sabiam ler } \\
\text { e } \\
\text { escrever } \\
43\end{array}$ & $\begin{array}{l}\text { Não } \\
\text { sabiam/ } \\
\text { não } \\
\text { assinaram }\end{array}$ & $\begin{array}{l}\text { Não identifi- } \\
\text { ficados }\end{array}$ & $\begin{array}{l}\text { \% de } \\
\text { Alfabetizados }\end{array}$ \\
\hline Cachoeira & $1941-59$ & 61 & 40 & 15 & 06 & $66 \%$ \\
\hline Nazaré & $1940-46$ & 32 & 23 & 07 & 02 & $72 \%$ \\
\hline S. A. Jesus & $1945-61$ & 32 & 22 & 08 & 02 & $69 \%$ \\
\hline C. Almas & $1961-65$ & 03 & 02 & 01 & 00 & $66 \%$ \\
\hline Totais & $1940-65$ & 128 & 87 & 31 & 10 & $67 \%$ \\
\hline
\end{tabular}

Fonte: Inventário realizado a partir dos processos consultados.

\footnotetext{
${ }^{43}$ Incluídas nesta categoria ações conjuntas em que, pelo menos, parte dos reclamantes sabia ler e escrever.

44 Processos em que, embora não haja referências expressas de que os reclamantes não sabiam ler e escrever, não foram identificadas assinaturas dos reclamantes. Em alguns casos, trata-se de ações conjuntas assinadas por procuradores, como advogados ou diretores sindicais.
} 
De acordo com o censo de 1950, 61,81\% dos habitantes do município de Cachoeira, 62,35\% de Nazaré e 72,49\% de Santo Antonio de Jesus não sabiam ler e escrever; situação que, de certa forma, expressava a realidade do Estado da Bahia cujo índice de analfabetismo chegava a $72,64 \%$ da população. Considerando-se os altos índices de analfabetismo predominantes nos três municípios, no período em tela, os dados apresentados na tabela sugerem que os trabalhadores alfabetizados poderiam acessar com mais facilidade as informações sobre a legislação trabalhista e a justiça do trabalho. Contudo, ao fim e ao cabo, demonstram também que muitos dos que tomaram tal iniciativa não sabiam ler nem escrever.

Um levantamento realizado por Maria Elisa da Silva, com processos referentes a acidente de trabalho na cidade de Salvador entre 1934 e 1944, apresentou resultados semelhantes. Entre os casos em que constava a escolaridade dos reclamantes (a autora não esclarece quantos) apenas $24,1 \%$ seriam analfabetos. Os dados apurados pela autora reforçariam, portanto, a tendência indicada pelos processos que analisamos. Ela adverte, entretanto, que em muitos dos processos não constava a escolaridade do trabalhador, sendo somente possível verificar se ele havia assinado ou não as atas ao final das audiências. $^{45}$

Outra tendência apontada nos processos aqui analisados diz respeito ao predomínio de não-sindicalizados entre os reclamantes e a rara presença de diretores ou assessores jurídicos de sindicatos ao lado destes, o que pode indicar que, em geral, a iniciativa de procurar a justiça do trabalho partia, voluntariamente, do próprio trabalhador. Isto nos permite concluir ainda que o sindicato era apenas uma das alternativas entre os possíveis aliados a que os trabalhadores recorriam na busca por informações e apoio jurídico na hora de formularem suas reclamações.

O acompanhamento sindical foi observado, geralmente, em algumas das reclamações movidas por trabalhadores da indústria fumageira e de usinas de açúcar, na Comarca de Cachoeira. Os dois setores constituíam as maiores concentrações operárias na região e contavam com uma maior tradição na formação de representação sindical. ${ }^{46}$ Além

\footnotetext{
45 SILVA, Maria Elisa Nunes. Entre trilhos, andaimes e cilindros: acidentes de trabalho em Salvador (1934-1944). Dissertação de Mestrado em História Social, Universidade Federal da Bahia, Salvador, Ba, 1998.

${ }^{46}$ De acordo com CUNHA (op. cit.) o primeiro sindicato dos trabalhadores no açúcar, do Recôncavo, foi fundado em 1935. Até 1943 possuía apenas 400 filiados. Em 1946, já na conjuntura do sistema corporativista, o
} 
destas, identificamos a assessoria sindical em duas outras ações movidas na mesma Comarca; uma aberta em 1942 por um empregado da Companhia de Energia Elétrica da Bahia - COELBA e a outra, aberta por um operário da construção civil, em 1947, teve o acompanhamento do Sindicato da Construção Civil de São Felix, Cachoeira e Muritiba. ${ }^{47} \mathrm{Em}$ Nazaré, apenas encontramos referências a um sindicato em duas ações coletivas de trabalhadores do curtume Nazaré, embora não tenhamos identificado a presença de nenhum representante sindical no acompanhamento dos processos. ${ }^{48}$

Mesmo quando se tratavam de ações plúrimas, nem sempre foi observada a presença de um sindicato. Foi este o caso de algumas reclamações movidas pelos trabalhadores da Companhia Minas da Bahia, responsável pela exploração de manganês no município de Santo Antonio de Jesus. A categoria não possuía sindicato ${ }^{49}$ e muitos dos que aparecem nos processos não sabiam ler e escrever. Contudo, além de inúmeras queixas individuais, constituíram, pelo menos, três ações plúrimas na Comarca local. Uma, de 1945, reuniu dez operários; outra, de 1950, contou com quarenta e cinco e na terceira, de 1957, aparecem doze trabalhadores. ${ }^{50}$

Esta mesma característica foi observada em duas ações formuladas na Comarca de Nazaré pelos operários da Companhia Hidro-Elétrica Fabril de Nazaré. A primeira, reivindicando o pagamento de uma gratificação de fim de ano, em dezembro de 1945, reuniu oitenta e cinco operários. ${ }^{51}$ A segunda, provocada pelo não pagamento do "salário

número de sindicalizados alcançava 10.000. Entre os trabalhadores do fumo, não sabemos exatamente quando surgiram os primeiros sindicatos, contudo, no período deste estudado eles abarcavam vários municípios. Havia, por exemplo, o Sindicato dos Trabalhadores na Indústria de Fumo das Cidades de São Félix e Cachoeira; o STIF das Cidades de Santo Antonio de Jesus, São Miguel das Matas e Amargosa, o STIF das Cidades de Muritiba Conceição do Almeida e Governador Mangabeira.

47 Refiro-me aos processos: de Amando Marques contra a Cia de Energia Elétrica da Bahia (COELBA) e de Vivaldo Bonifácio Costa contra o Hotel Colombo; ambos formulados na Comarca de Cachoeira, o primeiro em 18/8/1942 e o segundo, em 9/10/1947. APMC, Reclamações Trabalhistas, 1941-1949.

${ }^{48}$ Cf. Autos da Reclamação Trabalhista de Manoel Salvador de Oliveira, Luiz Antonio de Almeida e outros (71) contra a firma Drault e Cia e do Recurso Extraordinário de Manoel Salvador de Oliveira e outros (58) contra a mesma firma, ambos formulados na Comarca de Nazaré, em 6/7/1947 e em 11/4/1950, respectivamente. AFN, documentos sem catalogação.

49 Em matéria publicada em O Momento, em 15/6/1946, um dirigente comunista local afirma que eles teriam formado uma Associação Profissional e lutavam para transformá-la em sindicato, todavia não localizamos nenhum vestígio de que este tenha sido criado, tampouco aparece qualquer referência nas ações trabalhistas.

50 Refiro-me ao Recurso Ordinário de Bispo Evangelista, Noberto Santos, Sinfrônio Silva e outros, de 4/6/1945; à Reclamação Trabalhista de Vitor Alves Santos e outros, de 8/5/1950 e à Carta de Sentença de Quirino dos Santos e outros, de 1957; formuladas na Comarca de Santo Antonio de Jesus contra a Cia Minas da Bahia. Arquivo Público Municipal de Santo Antonio de Jesus (APMSAJ), Reclamações Trabalhistas, 1909-1958.

51 Recurso Ordinário da Cia Hidro-Elétrica Fabril de Nazaré contra Manoel Mauro Moura e Outros (84); Comarca de Nazaré, 11/7/1950. AFN, documento sem catalogação. 
compensação" ${ }^{52}$, em fevereiro de 1947, contou com a participação de setenta e sete operários. ${ }^{53}$ Nelas, aparecem como procuradores dos reclamantes o operário Fernando de Souza Nicori e o advogado Almir Bastos ${ }^{54}$; todavia não há nenhuma alusão à existência de sindicato. O mesmo pode ser observado numa ação de dissídio, de 1942, movida por doze operários da Companhia Mercantil Industrial (Olaria Jacaré) e numa ação de 1943 que reuniu oito empregados da Exportadora Bartilotti e Cia. Ambas, por demissão sem justa causa. ${ }^{55}$

Alguns operários, como Juvenal Martins dos Santos e José da Costa Nascimento, que apresentaram reclamações em 1941, na Comarca de Nazaré, contaram com a colaboração de um fiscal da DRT. ${ }^{56}$ Outros, em número maior, buscaram a assessoria do Ministério Público (MP). Em 11 de junho de 1954, um representante do MP formulou, na Comarca de Santo Antonio de Jesus, concomitantemente, sete ações individuais em nome de operários da Cia Minas da Bahia. ${ }^{57}$ Contudo, a maioria dos reclamantes ou contratava um advogado por conta própria, ou formulava pessoalmente suas reclamações com o auxílio do escrivão da Comarca.

Os trabalhadores que encontramos nos processos eram, em geral, provenientes de categorias diversificadas, conquanto houvesse maior incidência de uma ou de outra em cada Comarca. Apesar de muitos dos reclamantes serem identificados, genericamente, como operários, é possível inferir sobre as categorias profissionais a que pertenciam, a partir do tipo de atividade desenvolvida pela empresa em que trabalhavam.

$\mathrm{Na}$ Comarca de Santo Antonio de Jesus observou-se um predomínio dos trabalhadores da Companhia Minas da Bahia, responsável pela extração de manganês no município. De acordo com os autos de um dos processos analisados, a empresa chegou a

\footnotetext{
52 Estabelecido pelo Governo Federal, em função do Estado de Guerra, através do Decreto 5.979 de 10 de novembro de 1943.

53 Recurso Ordinário de Manoel Mauro de Moura e outros (74) contra a Cia Hdro-Elétrica Fabril de Nazaré; Comarca de Nazaré, 3/2/1947. AFN, documento sem catalogação.

54 Residia na cidade de Nazaré, aparece na maioria dos processos abertos nas Comarcas de Nazaré e de Santo Antonio de Jesus, atuando tanto em defesa de trabalhadores quanto de patrões.

${ }^{55}$ Ação de Dissídio de Misael Silva Galvão e outros (12) contra a Cia Mercantil Industrial, de 28/2/42 e Reclamação Trabalhista de Francisco Avelino Santos e outros (8) contra a empresa Exportadora Bartilotti e cia, de 29/3/1943; Comarca de Nazaré. AFN, documentos sem catalogação.

56 Refiro-me ao Processo de Dissídio Individual de Juvenal Martins dos Santos contra a firma Drault e Cia Ltda, de 19/7/1941 e à Ação de Dissídio de José da Costa Nascimento contra a firma Luiz Barreto Filho e Cia, de 16/12/1941; Comarca de Nazaré. AFN, documentos sem catalogação.

57 Refiro-me às Reclamações Trabalhistas dos operários: Valdemar Machado dos Santos e Astério dos Santos; Olimpio Bispo dos Santos; Florisvaldo Sena Ferreira; Damázio Muniz dos Santos; Irênio Silveira Ramos; João Pereira dos Santos; Antonio César Nascimento. Todas contra a Cia Minas da Bahia. APMSAJ, Reclamações Trabalhistas, 1909 a 1958.
} 
empregar "mil e muitos trabalhadores", constando ainda 246 nas folhas de pagamento de janeiro de 1954, já passado o auge da exploração do minério. ${ }^{58}$ As constantes paralisações nas atividades de mineração, geralmente acompanhadas pelo descumprimento ou suspensão dos contratos de trabalho e os freqüentes acidentes de trabalho, foram muitas vezes questionados na justiça, através de mais de uma dezena de ações, individuais e plúrimas. O fato de não haverem constituído uma representação sindical nem terem realizado greves não deve minimizar a capacidade demonstrada de mobilização e organização na luta por direitos. Outra categoria que se destaca numericamente nos processos da Comarca é constituída pelos operários da construção de estradas (rodovias e ferrovias). Geralmente contratados por empreiteiras e sujeitos às vulnerabilidades inerentes a tal modalidade de relação trabalhista, eles foram responsáveis pela formulação de outras sete reclamações.

Na Comarca de Nazaré há uma maior incidência, no período estudado, de reclamações formuladas pelos trabalhadores do Curtume Nazaré, de propriedade da firma Drault e Cia e também da Cia Hidro-Elétrica Fabril de Nazaré, fábrica do ramo de óleos vegetais e sabão. Em seguida aparecem os operários da Cia Mercantil Industrial Olaria Jacaré. Além de concentrarem um número significativo de operários, as duas primeiras categorias demonstram um nível bastante aguçado de organização e uma expressiva capacidade de mobilização na luta por direitos, sendo responsáveis pela formulação de ações individuais e plúrimas. Em relação aos trabalhadores da indústria de couro, encontramos alusão nos processos à existência de um sindicato. Em meados da década de 1940 o setor vivenciava uma grave crise, provocada pelo declínio da produção e do consumo, condenando vários trabalhadores ao desemprego. ${ }^{59}$

Em Cachoeira, encontramos uma grande diversidade de categorias entre os reclamantes. Contudo, destacam-se, numericamente, as ações dos trabalhadores dos armazéns de fumo e das fábricas de charutos e dos empregados das usinas de açúcar Vitória do Paraguaçu e Acutinga, localizadas na jurisdição daquela Comarca. Embora já não se encontrassem mais em seus melhores momentos, os dois setores continuavam sendo

\footnotetext{
58 Reclamação Trabalhista de Marcelino Francisco de Sousa contra a Cia Minas da Bahia, formulada na Comarca de Santo Antonio de Jesus, em 6/6/1945; Folhas de pagamento da Cia Minas da Bahia, de janeiro de 1954. APMSAJ, Reclamações Trabalhistas, 1909-1958 e folhas de pagamento da Cia Minas da Bahia.

${ }^{59}$ Cf. O Momento, 20/05/1947, p. 2.
} 
responsáveis pelas maiores concentrações operárias na região. Além do peso numérico, as duas categorias apresentavam um significativo grau de coesão e organização, sobretudo a primeira. Juntas, foram responsáveis, no período em questão, por mais de três dezenas de processos.

Em seu estudo sobre as charuteiras no Recôncavo, Elizabete R. da Silva também faz referência a existência de muitas reclamações e ações trabalhistas movidas contra as fábricas de charutos, após 1945 . No Correio de São Felix ${ }^{60}$, ela teria encontrado referência a dois dissídios coletivos, "de grande repercussão". Um deles, de julho de 1946, teria envolvido trabalhadores das fábricas Dannemann, Costa \& Penna e Suerdieck, que reivindicavam aumento de salários. O outro, de março de 1950, "já no contexto de dificuldades financeiras" das duas primeiras firmas, foi suscitado pelo Sindicato dos fumageiros, exigindo o pagamento de férias vencidas dos trabalhadores. Entre as correspondências internas da Dannemann, a autora também tivera acesso a notificações para comparecimento da empresa em cinco audiências trabalhistas a serem realizadas em 4 de maio de $1949 .{ }^{61}$

Por seu turno, os trabalhadores das usinas de açúcar - que tinham como núcleo principal o município de Santo Amaro - organizados em seu sindicato, além das inúmeras ações trabalhistas que formularam, foram responsáveis pelos mais expressivos movimentos grevistas ocorridos na Bahia, entre as décadas de 1940 e de $1950 .{ }^{62}$ Os fumageiros também possuíam representação sindical nas principais cidades onde estavam instalados os armazéns de fumo e fábricas de charutos, conquanto o nível de representatividade e de atuação variava muito entre os sindicatos. Diferentemente dos trabalhadores do açúcar, as fontes sugerem que, no período em questão, a categoria não demonstrou muita predisposição para a greve. Aparentemente, elegeu a via jurídica como principal estratégia de luta por direitos, sendo responsável por várias ações - tanto individuais, quanto coletivas.

\footnotetext{
60 Periódico de circulação local na época.

61 SILVA, Fazer charutos: uma atividade feminina, op. cit., p. 128.

62 Refiro-me ao movimento grevista encabeçado pelos trabalhadores das usinas ligadas à Lavoura e Indústria Reunidas, que durou quase um mês, em 1946; à paralisação dos trabalhadores da Usina Passagem, em virtude da demissão do operário Eduardo Carvalho, delegado sindical da referida usina, também em 1946; à greve dos trabalhadores da Usina Capanema, que durou 76 dias, entre dezembro de 1948 e fevereiro de 1949 e à greve que paralisou 2400 trabalhadores de campo da Usina São Carlos, em janeiro de 1949. Cf. O Momento, notas de várias edições.
} 
Os processos analisados indicam ainda um predomínio numérico do sexo masculino entre os reclamantes, embora as mulheres também sejam responsáveis pela formulação de várias reclamações individuais e tenham marcado presença em inúmeras ações coletivas, às vezes em meio a uma maioria masculina e noutras ocasiões sendo elas próprias maioria. Senão, vejamos:

TABELA 2 - RECLAMANTES X SEXO.

\begin{tabular}{|l|c|r|r|c|}
\hline COMARCA OU JUNTA & $\begin{array}{l}\text { No de trabalhadores } \\
\text { identificados }\end{array}$ & HOMENS & MULHERES & \% Feminina \\
\hline STo ANTo DE JESUS & 112 & 110 & 02 & $1,8 \%$ \\
\hline Nazaré & 338 & 323 & 15 & $4,5 \%$ \\
\hline Cachoeira & 126 & 95 & 31 & $24,6 \%$ \\
\hline JCJ Cruz as Almas & 275 & 64 & 211 & $76,7 \%$ \\
\hline TOTAIS & 851 & 592 & 256 & $30 \%$ \\
\hline
\end{tabular}

Fonte: Inventário realizado a partir dos processos consultados.

Os números referentes à Comarca de Nazaré e à Junta de Cruz das Almas merecem algumas ponderações. No caso de Nazaré, eles dizem respeito apenas ao período que vai de 1940 a 1946 e incluem quatro ações plúrrimas. Duas contra a empresa Drault e Cia, proprietária do Curtume Nazaré, reuniram 71 e 58 operários, todos do sexo masculino, sendo que a maioria dos nomes se repete nos dois processos. As outras duas, contra a Companhia Hidro-Elétrica Fabril de Nazaré, contaram com 84 e 74 operários, cuja maioria também aparece nas duas reclamações. Ambas tiveram a participação de apenas seis mulheres. Quanto à Junta de Cruz das Almas, os números dizem respeito a apenas três processos (que escaparam da incineração), dentre eles duas ações coletivas, formuladas, respectivamente em 1963 e 1965. A primeira reuniu 51 trabalhadores "tarefeiros" da Escola Agronômica da Bahia, sediada na cidade de Cruz das Almas, constando apenas sete do sexo feminino. A segunda, formulada pelo Sindicato dos Trabalhadores na Indústria de Fumo das Cidades de Muritiba, Conceição do Almeida e Governador Mangabeira, contra a empresa Carl Leoni, teve a participação de 194 mulheres entre os 212 reclamantes. 


\section{MULHERES E TRABALHADORES RURAIS NA JUSTIÇA DO TRABALHO.}

A maior ou menor participação de mulheres entre os reclamantes de uma ou de outra Comarca pode estar relacionada com os tipos de atividades que predominavam em cada sub-região. Nas áreas em que havia maior presença de mulheres operárias, como na região de Cachoeira, onde estavam localizados inúmeros armazéns de fumo e fábricas de charutos $^{63}$, elas aparecem com maior freqüência entre os reclamantes. Contudo, em Santo Antonio de Jesus, embora representassem uma parcela significativa dos empregados em atividades urbanas - o que pode ser explicado pela presença de alguns armazéns de fumo naquele município - as mulheres são menos comuns entre os reclamantes. Em Nazaré, elas pouco aparecem nos processos; o que pode ser explicado pela supremacia da mão-de-obra masculina nas atividades predominantes naquele município. ${ }^{64}$

Embora minoritária, a presença feminina entre os reclamantes representa uma importante manifestação de autonomia da mulher operária, não obstante as restrições sócio-culturais e econômicas impostas pela conjuntura e pela sociedade. Num contexto em que as representações dominantes sobre o sexo feminino carregavam uma enorme expectativa de comportamentos denotativos de fragilidade, dependência, submissão, docilidade e fidelidade, a subalternidade determinada pela condição de pobre e trabalhadora, vinculava-se também ao preconceito inerente à condição de mulher. ${ }^{65}$ Contudo, as mulheres que encontramos nos processos foram muito além dos papéis sociais que lhes estavam reservados no imaginário sócio-cultural da época. Longe da imagem de sexo frágil e submisso, sobressaem-se demonstrações de força, coragem, alteridade, consciência crítica em relação à sua própria condição de mulher e trabalhadora.

\footnotetext{
63 De acordo com Elizabete $R$ da Silva, as mulheres constituíam 70\% do universo da mão de obra empregada na fabricação de charutos. SILVA, Elizabete R. Fazer charutos: uma atividade feminina, op. cit.,

${ }^{64}$ Ver: SOUZA, Edinaldo A. O. "Lei e costume: experiências de trabalhadores na justiça do trabalho (RecôncavoSul, Bahia, 1940-1960)". Dissertação de Mestrado em História Social, Universidade Federal da Bahia, Salvador, $\mathrm{Ba}, 2008$.

${ }^{65}$ Demonstrações de tais representações encontram-se na própria argumentação empreendida pelos advogados das reclamantes, buscando justificar seus atos ou sensibilizar os magistrados, e na imprensa da época. Ou ainda, na própria CLT, quando concedia ao marido uma espécie de tutela sobre a mulher trabalhadora, igualando-a, neste caso, ao filho menor. Isto se verifica, por exemplo, no Parágrafo Único do artigo 446, que facultava ao marido ou pai, o direito de "pleitear a rescisão do contrato de trabalho, quando a sua continuação for suscetível de acarretar ameaça aos vínculos da família, perigo manifesto às condições peculiares da mulher ou prejuízo de ordem física ou moral ao menor".
} 
Geralmente, tendo que se desdobrar para conciliarem as tarefas da família e da casa com o emprego, para poderem garantir a própria sobrevivência e, não raras vezes, a de parentes - filhos, pais idosos, irmãos mais novos e até mesmo do marido ${ }^{66}$ - elas enfrentaram os gerentes, os patrões e seus procuradores jurídicos, cobraram das autoridades suas obrigações e certas vezes contestaram e até desafiaram as decisões dos magistrados. Na luta por direitos, também souberam lançar mão de atitudes de negociação e até mesmo tirar vantagens da própria condição de mulher, pobre e trabalhadora. Por vezes, a pseudo-imagem de sexo frágil, tradicionalmente imputada à condição de mulher, foi convertida em favor da trabalhadora e estrategicamente utilizada, inclusive na argumentação dos advogados, buscando justificar seus atos e até mesmo tentando sensibilizar os magistrados, geralmente do sexo masculino, em favor de suas causas.

Em 25 de setembro de 1942, Cassemira Evangelista Santos, analfabeta, casada e identificada profissionalmente como lavradora, abriu uma ação trabalhista, na Comarca de Nazaré, contra Areolinda Gomes, viúva, proprietária do terreno onde morava e trabalhava, no município de Santo Antonio de Jesus. Em sua petição, ela afirmou que no ano de 1933 seu marido, Francisco José dos Santos, havia contratado verbalmente uma "parceria agrícola" com a referida proprietária, para o cultivo de árvores frutíferas em seu terreno. De acordo com tal "contrato", plantariam mandioca "à meia" e fumo "à terça” e as benfeitorias, tais como árvores frutíferas, seriam de propriedade da reclamada, "tendo apenas o senhorio como compensação pelo terreno ocupado a meia da mandioca e o terço do fumo". Passados nove anos e tendo, durante este período, seu marido enlouquecido, a proprietária lhes mandou desocupar o terreno, sem pagar a devida indenização. ${ }^{67}$

Como a suplicante não the atendera, a proprietária solicitou à delegacia de polícia que providenciasse o despejo. Intimada a comparecer àquela instituição, perante o delegado e a patroa, Cassemira teria declarado que "não podia sair sem receber a indenização a que tinha direito". A autoridade policial então lhe respondeu que tal questão não era da sua competência, mandando-a procurar a justiça. Assim sendo, procurou o juiz de paz do Distrito, mas, segundo alega, nada foi resolvido. Fracassada tal iniciativa dirigiu-se ao pretor

\footnotetext{
${ }^{66}$ De acordo com Elizabete R. da Silva, a maioria das mulheres charuteiras era chefe de família, cabendo-lhe a manutenção da casa e da família no que diz respeito ao aspecto econômico, assim como a educação dos filhos e outras responsabilidades. SILVA, Elizabete R. Fazer charutos: uma atividade feminina , op. cit., p. 73.

67 Autos da Reclamação Trabalhista de Cassemira Evangelista Santos contra Areolinda Gomes; Comarca de Nazaré, 25/5/1942. AFN, documento sem catalogação.
} 
de Santo Antonio de Jesus, que mandou proceder administrativamente uma avaliação das roças e benfeitorias, que foram enfim calculados em três contos e doze mil réis. ${ }^{68}$

Chamada em audiência, a proprietária teria acertado com o pretor o pagamento da referida indenização. Porém, tendo este último viajado à capital do Estado para tratar de questões de interesse pessoal, teria voltado atrás e se negando a efetuar indenização nas condições acertadas. Havia constituído um advogado e, reiterando a ameaça de despejo, entregou à reclamante apenas um conto de réis a título de indenização. Nessas circunstâncias, teria sido lavrada, em cartório, uma escritura estipulando o prazo de trinta dias para a desocupação do terreno. Em sua petição, a reclamante alegou que não foi informada sobre o conteúdo do documento, que não sabia se era "de quitação ou de venda da benfeitoria". Afirmou ainda que foi "coagida, atordoada e amedrontada" e que teria sido vítima de um "esbulho" praticado pela proprietária, "à sombra de sua ignorância" e da condição de "analfabeta e desacompanhada". Acrescentou ainda que estava com o conto de réis recebido em mãos, intacto, "pois ficou tão atordoada que no momento não pôde recusá-lo, quando lhe meteram nas mãos" ${ }^{69}$

Ainda de acordo com a argumentação aludida pela reclamante, os "homens da justiça de Santo Antonio de Jesus" Ihe teriam dito que não tinha nenhum direito a reclamar, razão pela qual decidiu procurar "a justiça de V. Exạ", o juiz da Comarca de Nazaré. A este último, pediu a "reparação do esbulho que sofrera, em virtude de sua timidez de mulher rústica e analfabeta, que só entende de lavoura", a concessão do "favor legal da assistência judiciária a fim de defender os seus direitos" e entregou-lhe a quantia de um conto de réis "que maliciosamente lhe foi dada". Jurou ainda "que não anuiu a transação que engendraram, espoliando-lhe nove anos de trabalho ao sol e chuva, ficando com as mãos calejadas pela enxada, espoliada e abandonada com um marido louco". Por fim, afirmou que se encontrava "em situação precária, proibida de colher suas roças, não sendo indenizada no valor das suas benfeitorias". ${ }^{70}$

Em sua defesa, a proprietária afirmou que a decisão de mandá-la desocupar o terreno deveu-se ao fato de a reclamante não vir pagando a parte da meia. Que como não Ihe fora entregue o dito imóvel, tampouco ocorrido nenhum acordo, promoveu os meios

\footnotetext{
68 Idem.

69 Idem.

70 Idem.
} 
necessários para que fosse efetuado o despejo, conforme ação corrente no termo de Santo Antonio de Jesus. Ouvidas as partes e as respectivas testemunhas, chegou-se a uma conciliação em que a trabalhadora comprometeu-se a entregar o terreno e a casa no prazo improrrogável de trinta dias, com a condição de a patroa pagar-lhe mais seiscentos mil réis, além do conto de réis já pago por intermédio do seu advogado. ${ }^{71}$

Aqui, a condição de mulher, combinada com adjetivos como "desacompanhada", "atordoada", "amedrontada", "enganada" e "espoliada", e a de trabalhadora rural, combinada com "analfabeta", "rústica", "ignorante", "que só entende de lavoura" são estrategicamente utilizadas pela trabalhadora e por seu advogado. As tradicionais retóricas que primavam por uma pseudo-fragilidade feminina e por uma pseudo-ignorância dos roceiros - ambas negadas pela experiência da própria reclamante - foram apropriadas e convertidas em mais um recurso, buscando justificar atitudes da trabalhadora e até mesmo influenciar na decisão do magistrado. Ainda que, para isso, tenha recebido orientação do bacharel, a reclamante não deve ter encontrado maiores dificuldades para entender e representar os referidos papéis.

Estudando o comportamento de mulheres operárias no Rio de Janeiro no início da República, Sidney Chalhoub observou que a tendência de a mulher pobre exercer atividades remuneradas Ihe possibilitava uma "relativa independência em relação a seu homem" e que "ela soube muitas vezes asseverar esta sua condição com altivez e, até, com orgulho", constituindo-se, portanto, "um aspecto essencial da construção da sua identidade social" ${ }^{72}$ Em estudo recente, Cristiana Schettini obteve conclusões semelhantes em sua análise das prostitutas no Rio de Janeiro. ${ }^{73}$ É certo que os ganhos econômicos e mesmo o prestígio auferido por alguns empregos ou ofícios - como o de charuteira - devem ter influenciado mudanças nas relações de gênero e, provavelmente, na auto-estima feminina, mas não se deve pressupor uma relação mecânica entre essas condições e atuação da mulher na luta por direitos. Contudo, as situações relatadas nos autos dos processos demandam uma análise mais sofisticada.

\footnotetext{
71 Idem.

72 CHALHOUB, Sidney. Trabalho, lar e botequim: o cotidiano dos trabalhadores no Rio de Janeiro da belle époque, 2a ed. Campinas, SP: Editora da Unicamp, 2001, pp. 204 e 207.

73 PEREIRA, Cristiana Schettini. "Que tenhas teu corpo". Uma história social da prostituição no Rio de Janeiro das primeiras décadas republicanas. Rio de Janeiro: Arquivo Nacional, 2007.
} 
O fato de estarem mais presentes no espaço púbico, mais expostas ao convívio com outras pessoas - nos espaços da vizinhança, do local de trabalho e do lazer - conferia à mulher operária uma posição mais autônoma e um maior acesso às informações, facultando-Ihes assim uma avaliação da realidade mais impregnada de significados. Isso, provavelmente, ampliava as expectativas femininas, bem como as suas perspectivas e possibilidades no que concerne às estratégias de ação. A iniciativa de acionar a justiça e o percurso das ações indicam que as manifestações de autonomia das mulheres trabalhadoras não estavam limitadas ao espaço privado da relação familiar. O processo supracitado sugere, ainda mais, que atitudes não podem ser creditadas apenas à inserção feminina no mercado urbano de trabalho.

O próprio Chalhoub, voltando seu olhar para o século XIX observou que mesmo numa sociedade cujos ideais de dominação de classe tenham como fundamento a perspectiva da inviolabilidade da vontade do patriarca, era possível comportar alguma margem de autonomia em favor dos dominados. A ideologia patriarcal-senhorial não era capaz de anular "valores, conceitos, formas de interpretar a realidade que negam, ou pelo menos relativizam" a eficiência de sua ação. Não vedava a possibilidade de que a mulher assim como os demais "sujeitos subalternos" - se apropriassem dos seus mecanismos de funcionamento e os decodificassem a partir de visões de mundo particulares. ${ }^{74}$

Neste sentido, a prevalência hegemônica de um sistema de dominação de classe, impregnado de valores patriarcais, em que a condição de mulher e de trabalhadora acumulava as implicações da opressão econômica - geralmente permeada por mecanismos de disciplina - e da subordinação sexual, não anulava a possibilidade de elas atuarem enquanto sujeitos ativos, também nas relações de trabalho. $O$ ato de colocar o patrão na justiça pode ser entendido como uma manifestação multifacetada de independência e coragem da mulher trabalhadora. Uma reação perante uma relação que era, ao mesmo tempo, de exploração econômica e de discriminação sexual. Como trabalhadora lutava pelos direitos instituídos pela legislação trabalhista e como mulher buscava o reconhecimento, em suas peculiaridades, da condição de trabalhadora e de cidadã.

${ }^{74}$ Cf. CHALHOUB, Sidney. Machado de Assis: historiador. São Paulo: Companhia das Letras, 2003, p. 30. 
Outra peculiaridade inerente às reclamações femininas diz respeito à questão do direito à licença maternidade. ${ }^{75}$ Os conflitos em torno da sua realização geralmente explicitavam tensões atinentes às relações de gênero que permeavam o cotidiano de trabalho. Tal foi o caso relatado pela operária Etelvina Santos, solteira, que em 14 de novembro de 1945 reclamou na Comarca de Cachoeira contra a firma L. Barreto Filho e Cia, responsável pelo armazém de fumo onde trabalhava. Na ocasião, a reclamante alegou que ao solicitar do gerente da empresa a concessão do auxílio maternidade, teria ouvido como resposta "que ali não era o Banco do Brasil, pois as operárias fabricavam filhos e depois iam lá buscar dinheiro". Como testemunha, indicou duas outras mulheres, Maria Marta do Nascimento e Maria de Lurdes Ramos, sobre as quais não temos informações se eram colegas de trabalho. ${ }^{76}$

Em contrapartida, a defesa da empresa consistiu na alegação de que a operária havia sido contratada "por safra", tratando-se assim de um "serviço temporário" e que quando ela requereu o referido direito seu contrato já havia expirado, em virtude de paralisação nas atividades do armazém. Alegou, também, que na época da solicitação, a reclamante ainda não fazia jus a tal benefício, pois a lei previa sua concessão entre seis semanas antes e outras seis depois do parto, conquanto, passaram-se dois meses e ela ainda não havia dado a luz à criança. ${ }^{77} \mathrm{O}$ mesmo argumento foi utilizado pela firma perante a reclamação de Marciana Soares da Conceição, também mãe solteira, aberta em 20 de outubro de $1945 .^{78}$

No primeiro caso, o juiz da Comarca alegou falta de prova, da parte da reclamante, no que concerne à natureza do contrato de trabalho e acatou a defesa da empresa julgando

\footnotetext{
75 A Constituição de 1937, em seu art. 137, já previa que a legislação do trabalho observaria, além de outros preceitos: a "assistência médica e higiênica ao trabalhador e à gestante, assegurado a esta, sem prejuízo do salário, um período de repouso antes e depois do parto". Posteriormente a CLT, em seu art. 392, proibiu o trabalho da mulher grávida, seis semanas antes e seis depois do parto; podendo ainda, em casos excepcionais, os referidos períodos serem aumentados em mais duas semanas, cada um, mediante atestado médico. Já o art 393 definiu que durante este período a mulher teria direito aos salários integrais, calculados de acordo com a média dos últimos seis meses de trabalho, sendo-lhe ainda facultado reverter à função que anteriormente ocupava. Em parágrafo único, estabelecia ainda que a concessão de auxílio maternidade por parte da instituição da previdência social não isentaria o empregador da referida obrigação. Os termos desta redação perdurariam inalterados até a publicação do Decreto-Lei no 229 de 28/2/1967.

76 Cf. Autos da Reclamação Trabalhista de Etelvina Santos contra L. Barreto Filho e Cia; Comarca de Cachoeira, 14/11/1945, APMC, Reclamações Trabalhistas, 1941 a 1949.

77 Autos da Reclamação Trabalhista, citada, de Etelvina Santos.

${ }^{78}$ Cf. Autos da Reclamação Trabalhista de Marciana Soares da Conceição contra L. Barreto Filho e Cia; Comarca de Cachoeira, 20/10/1945. APMC, Reclamações Trabalhistas, 1941 a 1949.
} 
a reclamação improcedente. No segundo, não foi localizada a conclusão do processo, constando apenas uma petição - em anexo - na qual a reclamante afirma que quando recomeçou o serviço dos armazéns fora pedir ao gerente que lhe desse trabalho, tendo ouvido deste que não havia emprego para ela, por ter procurado a justiça do trabalho contra seus empregadores, além da "ironia" de que "seu patrão não botou armazém de fumo para ela trabalhar". ${ }^{79}$

Situação semelhante foi vivenciada por Anatildes de Jesus, também solteira, analfabeta, que, em 12 de março de 1943, reclamou na Comarca de Cachoeira contra Falcão e Cia, responsável pela fábrica de charutos onde trabalhava. De acordo com as alegações da operária, "a firma empregadora, desatenta às determinações das leis sociais", teria Ihe negado o benefício da licença maternidade, "sob a alegação de não ser a reclamante casada". Na oportunidade, acrescentou ainda que jamais lhe foram concedidas férias, pedindo ao juiz que determinasse providências no sentido de que lhe fosse pago, pela firma empregadora, dois meses de salário, com valor equivalente ao salário mínimo estabelecido para a zona, e três períodos de férias - um em dobro, o outro simples. Como anteparo jurídico, citou os arts. 16 e 27 do decreto 23.768 de $1934^{80}$ e o art. 137 da Constituição Federal de 1937. Não foram localizados, neste caso, a defesa do empregador nem o desfecho do processo. ${ }^{81}$

Apesar de argüido pelos patrões, o alijamento da mãe solteira do direito à licença maternidade não encontrava nenhuma guarida na legislação trabalhista. Trata-se, na verdade, de um artifício de natureza preconceituosa, empregado com o intuito de ludibriar a pretensão da trabalhadora. Assim sendo, perante os tribunais, o argumento utilizado pela defesa, nos casos analisados, centrava-se essencialmente na alegação de eventualidade, transitoriedade e expiração do contrato de trabalho. Embora a sonegação dos direitos trabalhistas e a intolerância do chefe, diante de cobranças advindas dos subordinados, independessem do sexo do trabalhador, parece que tais procedimentos se avultavam em relação às mulheres solteiras, mormente quando grávidas e a solicitarem a licença maternidade. Situação que pode configurar uma questão de gênero. Ou seja, o preconceito

\footnotetext{
79 Autos da Reclamação Trabalhista, citada, de Marciana Soares da Conceição.

${ }^{80} \mathrm{O}$ referido decreto regulava a concessão do direito de férias aos empregados na indústria, mas limitava seu acesso aos trabalhadores sindicalizados.

${ }^{81}$ Cf. Autos da Reclamação Trabalhista de Anatildes de Jesus contra a firma Falcão e Cia; Comarca de Cachoeira, 12/3/1943. APMC, Reclamações Trabalhistas, 1941 a 1949.
} 
pela condição de mulher e de mãe solteira aumentava, ou abonava, a intolerância do chefe ao ser interpelado pelo empregado sobre direitos. O recurso à justiça foi, portanto, uma importante manifestação da atuação da mulher operária, enquanto sujeito ativo, na luta por direitos - não apenas trabalhistas, mas também das mulheres - e pela ampliação das noções e práticas de cidadania.

Igualmente, merece uma menção especial à presença, ainda que em menor escala, de trabalhadores rurais domésticos entre os reclamantes, dadas as peculiaridades inerentes às práticas de trabalhos predominantes no meio rural, as limitações impostas pela própria legislação trabalhista a essas duas categorias e a distância e/ou ineficiência dos organismos de fiscalização e justiça, notadamente, em relação à primeira.

No mesmo ano em que foi movida a reclamação de Cassemira Evangelista, na mesma Comarca, outra trabalhadora rural, de nome Narcisa Ferreira de Jesus, analfabeta, formulou uma reclamação contra o Sr. Antonio Geraldino de Carvalho. Este havia contratado seus serviços, em 1940, para tomar conta de um sítio adquirido através de arrendamento. Conforme haviam combinado, ela deveria cuidar de trinta porcos nos currais e colher dendês para o fabrico de azeite, entregando-Ihe o viscoso óleo em latas. Em contrapartida, o locador dos serviços se comprometera a pagar-lhe a quantia de cento e vinte mil réis mensais, ou seja, um conto, quatrocentos e quarenta mil réis por ano. ${ }^{82}$

Terminado o primeiro ano de serviços prestados, a trabalhadora pediu ao patrão que descontasse pequenas quantias que havia tomado ao longo do tempo e the pagasse o saldo, calculado em mais de um conto de réis. Mas fora convencida por ele de que era melhor não recebê-lo, pois o gastaria, e que deixasse em suas mãos, que o depositaria na Caixa Econômica, onde renderia juros, podendo ela depois retirá-lo e comprar uma casinha. Em janeiro de 1942 ela voltou a solicitar ao patrão o saldo - então referente aos dois anos sendo por isto despedida sem receber "um níquel sequer" dos salários, nem indenização “pela despedida sem prévio aviso" e nem "as férias a que também tem direito". Pediu, então, que fosse julgada a sua queixa, para condenar o patrão ao pagamento dos ordenados retidos e demais direitos, conforme a Lei 62 de 1935. Estrategicamente, apresentou-se como

\footnotetext{
82 Autos da Reclamação Trabalhista de Narcisa Ferreira de Jesus contra Antonio Geraldino de Carvalho; Comarca de Nazaré, 24/3/1942. AFN, documento sem catalogação.
} 
proletária, não obstante algumas das funções que exercia se enquadrassem entre as que aludem à condição de trabalhador rural. ${ }^{83}$

Em contrapartida, o patrão negou a dívida, afirmando que ela recebia todos os sábados a quantia de doze mil e quinhentos réis, "porquanto foi por essa importância que ele havia combinado com ela o serviço" e acrescentou que nunca prometera pagar à reclamante a quantia de cento e vinte mil réis mensais. Procurou ainda desqualificar a conduta da reclamante, alegando atitudes de indisciplina e irresponsabilidade no serviço. Por fim emendou que, além de desobedecer as suas determinações, ela teria procurado pessoas que the convinha "para que providenciasse no sentido de ser feita a reclamação". Em audiência, realizada ainda no âmbito da Comarca, procedeu-se a conciliação entre as partes, à razão de duzentos mil réis em favor da reclamante. ${ }^{84}$

Sabe-se que a política trabalhista, no que concerne à legislação social e à justiça do trabalho, a princípio, alcançou de forma mais incisiva os operários urbanos, sobretudo os das grandes cidades, onde havia uma maior incidência de sindicalização - pré-requisito exigido para o acesso dos trabalhadores a alguns dos direitos estabelecidos em lei. Inicialmente apenas estes lugares foram dotados de alguma infra-estrutura indispensável ao funcionamento de tais organismos. Como já vimos anteriormente, as poucas JCJ estiveram, por muito tempo, localizadas apenas nas capitais e nalgumas importantes cidades industriais. Os TRTs também foram implantados nas capitais estaduais de maior concentração demográfica e industrial.

Como vimos, a primeira JCJ do Recôncavo só foi criada em 1958, na cidade de Cachoeira e, ainda assim, com a jurisdição limitada às Comarcas de Cachoeira, São Felix, São Gonçalo dos Campos e de Maragogipe. Insuficiente e controversa era também a atuação dos fiscais do trabalho, alvo constante de críticas e denúncias na imprensa operária da época, tanto pela insuficiência numérica, quanto por omissão e suposto comprometimento com os setores patronais. ${ }^{85}$ Assim sendo, o aparato institucional encarregado de zelar pelo cumprimento da legislação trabalhista nas cidades do interior era, precariamente, constituído pelos fiscais do trabalho e pelos juízes de Direito das Comarcas. Isso,

\footnotetext{
83 Idem.

84 Idem.

${ }^{85}$ Refiro-me aos periódicos O Momento e Correio Trabalhista.
} 
certamente, constituía um obstáculo ao acesso dos trabalhadores rurais aos benefícios da legislação trabalhista.

Entretanto, este não era o único entrave que dificultava o acesso dos trabalhadores rurais às "benesses" da política trabalhista. Outro estaria na própria complexidade das práticas de trabalho presentes nas áreas agrícolas no Brasil, que dificultavam a construção de uma identidade de classe entre os trabalhadores rurais. ${ }^{86}$ No Recôncavo Sul, conforme observou Charles Santana, "dificuldades de lidar com os registros escritos e impessoais, com advogados e juízes do trabalho, provocavam os sujeitos históricos a interpretarem os possíveis avanços com 'medo' e como 'ousadia'”. Segundo o autor, "a inadequação destas leis à cultura das relações de trabalho na região" - geralmente baseadas em noções costumeiras de direitos e em "acertos" verbais - "proporcionou o surgimento de problemas novos e difíceis de serem incorporados ao mundo do trabalhador rural" ${ }^{87}$ Outro entrave se encontrava na forte resistência do patronato rural que tentava, a todo custo, "entrincheirar" suas propriedades ante o avanço das prerrogativas estatais. De acordo com Santana, "a obrigatoriedade da aplicação das leis trabalhistas e o registro dos empregados inviabilizavam a manutenção de meeiros e rendeiros" na região. ${ }^{88}$

Também, não podemos desconsiderar que a CLT impôs restrições á participação de trabalhadores rurais e empregados domésticos nas suas disposições jurídicos, visto que seu art. 7으 estabeleceu que:

Os preceitos constantes da presente Consolidação, salvo quando for, em cada caso, expressamente determinado em contrário, não se aplicam:

a) aos empregados domésticos, assim considerados, de um modo geral, os que prestam serviços de natureza não-econômica à pessoa ou à família, no âmbito residencial destas;

b) aos trabalhadores rurais, assim considerados aqueles que, exercendo funções diretamente ligadas à agricultura e à pecuária, não sejam empregados em atividades que, pelos métodos de execução dos respectivos trabalhos ou pela finalidade de suas operações, se classifiquem como industriais ou comerciais.

\footnotetext{
${ }^{86}$ WELCH, C. The Seed Was Planted. The São Paulo Roots of Brazil's Rural Labor Movement, 1924-1984. Pennsylvania: Pennsylvania University Press, 1999; DEZEMONE, Marcus. "Do cativeiro à reforma agrária: memória, direitos e identidades em terras de café (1888-1987)". Anais do XII Encontro Regional de História: usos do passado. Niterói: Anpuh-Rio, 2006. Ver também: PRIORI, Ângelo. O protesto do trabalho: história das lutas sociais dos trabalhadores rurais do Paraná: 1954-1964. Maringá: EDUEM, 1996.

87 SANTANA, C. A., op. cit., p 116.

88 Ibidem, p.116.
} 
Sem perder de vista tais limitações, os resultados atualmente alcançados por algumas pesquisas têm permitido questionar a tese da existência de um "pacto oligárquico", patrocinado pelo Estado, que teria determinado a "exclusão dos trabalhadores rurais" das diretrizes da política trabalhista. Há evidentes indícios de que tanto Getúlio Vargas quanto parte da sua burocracia entendiam que a inclusão do setor rural era uma condição essencial para o êxito de tal projeto político. Para além da retórica presidencial, algumas ações efetivamente realizadas pelo Estado acenavam nessa direção, embora enfrentassem a forte resistência das elites agrárias. ${ }^{89}$ A própria CLT, como observou Cliff Welch, "para desgosto dos fazendeiros [...] aplicava aos trabalhadores rurais e urbanos regras gerais parecidas quanto a: salário mínimo, férias, contrato de trabalho, aviso prévio e limitações para pagamentos em bens em vez de moeda corrente". Estas medidas deram aos trabalhadores rurais um conjunto, embora limitado, de direitos fundamentais. ${ }^{90}$

Marcus Dezemone também assinalou que "o exame mais atento dos demais artigos da CLT permite identificar uma tensão entre essa exclusão e a inclusão dos trabalhadores rurais em alguns direitos". Ademais, "na ausência da norma jurídica específica, o juiz tem autonomia para julgar baseando-se na jurisprudência, na analogia ou nos princípios gerais de direito". Assim sendo, "não era a inexistência de uma lei que versasse sobre a matéria que impedia o acesso dos trabalhadores rurais ao Poder Judiciário". Alguns estudos têm demonstrado que "o impacto da CLT no mundo rural foi muito importante na solução jurídica de conflitos" e que "as ações de trabalhadores do campo contra seus patrões foram mais freqüentes do que se imaginava". ${ }^{91}$ Destarte, os casos analisados sugerem que,

Mais do que geralmente se admite, a legislação trabalhista - cujo zelo e interpretação eram legalmente atribuídos à justiça do trabalho [...] não criou mundos apartados entre os beneficiados e os excluídos. Aqueles que não foram contemplados reivindicaram seu lugar, contando com o apoio dos que haviam sido agraciados, inclusive. ${ }^{92}$

\footnotetext{
89 Sobre a relação do projeto trabalhista com os trabalhadores rurais, ver discursos proferidos por Getúlio Vargas durante as comemorações do 10 de maio de 1941 (anunciando o início do funcionamento da Justiça do Trabalho) e de 1943 (quando do anúncio da CLT).Ver também DEZEMONE, M. "Impactos da Era Vargas no mundo rural: leis, direitos e memória". In: Perseu: história, memória e política, vol. 1, no 1. São Paulo: Editora Fundação Perseu Abramo, 2007; WELCH, C., op.cit.

90 WELCH, Cliff, op. cit., p.36

91 DEZEMONE, Marcus. "Impactos da Era Vargas no mundo rural: leis, direitos e memória”, op. cit., p. 183. Ver também: ___. "Do cativeiro à reforma agrária: memória, direitos e identidades em terras de café (1888-1987)", op. cit e WELCH, C., op.cit..

${ }^{92}$ NEGRO, Antonio Luigi. "O que a Justiça do Trabalho não queimou: novas fontes para o estudo do trabalho no século XX." Conferência apresentada no projeto História em Debate, ciclo I, promovido pelo Depto de História da UESB. Vitória da Conquista, Ba, setembro de 2006, p. 11.
} 
Igualmente, como observou Dezemone, as ações judiciais dos lavradores, baseadas na CLT e no Código Civil de 1916, e o acolhimento dessas demandas pela justiça, tanto a do Trabalho (Especial) quanto pelas Varas Cíveis (Comum) revelam uma circularidade de informações que pode ajudar a melhor compreender o porquê do lugar privilegiado ocupado por Getúlio Vargas na memória de trabalhadores rurais, no período. ${ }^{93}$ Além disso, teria contribuído para a formação de uma "cultura de direitos" entre os trabalhadores rurais. ${ }^{94}$

\section{A JUSTIÇA DO TRABALHO COMO PALCO DE TENSÕES E NEGOCIAÇÕES.}

As ações dos trabalhadores na justiça representaram, antes de tudo, uma manifestação das tensões vivenciadas no cotidiano das relações de trabalho, notadamente relacionados às disputas por direitos e poderes que, não raras vezes, chegavam às vias de fato. Para além de interesses econômicos, exprimiam também sentimentos e crenças envolvendo questões de trabalho, honra, dignidade e honestidade.

Em 1946, o operário Florêncio Anastácio da Luz reclamou, na Comarca de Nazaré, de uma suspensão que Ihe fora aplicada pela Companhia Hidro-Elétrica Fabril de Nazaré, por ter se recusado a realizar uma tarefa alheia ao seu contrato de trabalho. Contratado, desde 1929, para realizar serviços internos da fábrica de óleos vegetais e sabão da referida empresa, teria recebido ordem do chefe de serviço para acompanhar um carregamento que seguiria de barco com destino à capital. Além de considerar o serviço estranho ao seu contrato de trabalho, o reclamante alegou não dispor de agasalhos para realizar a referida viagem, em tempo de inverno. Fez questão de acrescentar que noutras duas ocasiões, quando as condições do tempo permitiam e lhe era conveniente, havia atendido, porém desta vez teria recusado "para não fazer hábito". Inconformado, o "superior" foi impelido a mandar outro empregado em seu lugar, aplicando-lhe, porém, uma suspensão "por desobediência". 95

\footnotetext{
93 DEZEMONE, M. “Do cativeiro à reforma agrária...”, op. cit., p.8.

94 Idem. "Impactos da Era Vargas no mundo rural...", op. cit, p. 197.

95 Reclamação Trabalhista de Florêncio Anastácio da Luz contra a Companhia Hidro-Elétrica Fabril de Nazaré S/A, aberta na Comarca de Nazaré, em 9/1/1947. AF N, documento sem catalogação.
} 
Perante o exposto, algumas questões se sobressaem. Primeiramente, a percepção de que, embora se mostrassem freqüentemente dispostos a cooperar com os chefes, os trabalhadores eram capazes de discernir, com precisão, diferenças entre cooperação e obrigação. Sentiam-se, portanto, no direito de definir em tal ou qual circunstância era conveniente ou não colaborar. Depois, a observação de que as punições impostas, arbitrariamente, pelos chefes aos trabalhadores, mediante multas, suspensões e demissão, passavam a ser, freqüentemente, questionadas na justiça. Logo, para os trabalhadores, este se tornava um meio legítimo de tentar assegurar direitos sonegados, reaver direitos subtraídos ou resguardar direitos ameaçados.

Chegou às vias de fato, por exemplo, o conflito entre o operário Crispiniano Oliveira dos Santos e o gerente da Olaria Jacaré, que resultou na formulação de um dissídio trabalhista na Comarca de Nazaré, em 10 de outubro de 1944. O reclamante alegou que trabalhava para a referida empresa desde fevereiro de 1937 e que fora despedido sem justa causa e sem receber a indenização devida "nos termos da CLT". O motivo da demissão seria um desentendimento com o gerente da empresa, motivado por um desconto efetuado na quantia que Ihe devia ser paga, relativa ao período de férias. Inconformado, o empregado se dirigiu ao escritório da firma para questionar o referido desconto. Porém, irritado com a sua "ousadia", o chefe o teria expulsado aos gritos, empurrões e pontapés e recomendado ainda que não voltasse mais ao trabalho. Em contrapartida, a empresa alegou insubordinação, indisciplina e abandono do trabalho, por parte do empregado. Este, "sem motivo plausível", mas somente por ter sido descontado do seu salário "o que prometera" por amortização de um empréstimo, teria se insubordinado, chegando a travar luta física com o gerente e, em seguida, abandonado "espontaneamente e ostensivamente o trabalho" ${ }^{96}$

Alegações de indisciplina, insubordinação, negligência e abandono do emprego por parte do reclamante, geralmente integravam a estratégia de defesa patronal perante a acusação de demissão ou de punições (como multas e suspensões) consideradas injustas pelo trabalhador. Lançando mão de tais argumentos, tentava-se descaracterizar a acusação de demissão injustificada e enquadrar a situação como abandono de emprego ou demissão por justa causa. Entretanto, no caso em tela, não podemos descartar a possibilidade de o referido desconto ter sido aplicado efetivamente com o objetivo de amortizar uma suposta

\footnotetext{
96 Idem.
} 
dívida contraída pelo empregado, decorrente de um suposto empréstimo acordado verbalmente com o patrão. A ação foi acolhida pelo juiz, mas a firma apelou da decisão alegando incompetência da Comarca para julgar a referida questão. Da conclusão do processo consta apenas a penhora de uma máquina destinada à fabricação de telhas, do tipo "francesa", avaliada em cinco mil cruzeiros; um "bem imprestável", segundo o advogado do reclamante. $^{97}$

Os acontecimentos relatados nos autos da ação apontam ainda para a convivência de práticas tradicionais - como o suposto empréstimo de dinheiro ao empregado com a garantia verbal de liquidação à época do pagamento das férias e a prática da violência física como desdobramento de conflitos do trabalho - com a legislação e a justiça formais, como fatores de tensão nas relações de trabalho. Assim sendo, sem discordar que a lei "anunciou o longo declínio da eficiência dos velhos métodos de controle e disciplina de classe, e sua substituição por um recurso padronizado de autoridade ${ }^{\prime 98}$, é prudente acrescentar que a afirmação do domínio da lei não significou a supressão imediata das práticas tradicionais, como às vezes se supõe. Antes, teria sido um processo lento, marcado por conflitos e acomodações.

As audiências trabalhistas quase sempre transcorriam sob um forte clima de tensão. Mesmo nas situações que resultaram em conciliação, esta geralmente foi precedida de conflitos, disputas jurídicas, trocas de acusações, ameaças, etc. A própria lei, como nos informa E. P. Thompson, constituía um espaço aberto ao conflito. ${ }^{99}$

\footnotetext{
97 Idem.

98 THOMPSON, E. P., Senhores e caçadores, op. cit, p. 282.

99 Ibidem.
} 
